\title{
The Onset of Emigration from Iceland
}

By

Helgi Skúli Kjartansson

University of Iceland, Reykjavik

For a third of a century, from 1873 to 1905, Iceland ranked high among the emigration areas of Europe, the annual number of migrants per 1000 reaching about 13 for $1885-89^{1}$ and almost equalling that of Norway for the entire period.

After 1905 Icelandic emigration is, by contrast, relatively insignificant. It drops sharply in 1906, before the American panic of 1907, and after the crisis it never recovers to anything like the same extent as in the Scandinavian countries or the British Isles.

Before 1873 emigration is conspicuous by its almost total absence, even around 1870 when it is rampant in every country with which Icelanders have contacts. This situation deserves a closer look.

The years 1859 through '72 were in Iceland characterized by agricultural distress (resulting from climatic deterioration and a sheep epidemic) and sluggish population growth $(0.2 \%$ p.a. $)$. The latter reflects partly the echo effect on fertility, but only partly as both mortality and age-specific fertility are involved. The fertility drop occurred with the largest cohorts of adults still in their midtwenties, well below the average age of parents, which may suggest that the previously fast-growing $(1.4 \%$ p.a.) population was now pressed against the ceiling of resources, lowered by the harsh climate. This impression is strengthened by the increasing size of households and above all by reduced nuptiality, especially at lower ages. One can hardly doubt that many Icelanders experienced a lowering of their living standards and that the young people in particular were now confronted by much more limited opportunities than their parents in the 1840's and '50's. The Icelanders would, in other 
words, have had the most classic economic reasons to emigrate before 1873 .

Let us not forget those few who did, even to original destinations like Utah and Brazil.

Mormon missionaries (converted in Denmark) recruited some sixteen emigrants in the late 1850's. The mission was resumed in 1872 and contributed to the mass emigration in the following years, but only locally; the most important foci of emigration were untouched by Mormonism.

As early as 1859 the bad outlook for agriculture had prompted the inhabitants of the bard-hit North to contemplate emigration and even to form an association for that purpose. Somehow they came to set their hopes upon free or assisted passage to Brazil and repeatedly contacted Brazilian agents. But they failed in their arrangements for transport. The first small group (except for a few explorers) did not reach their chosen country until 1873 when the tide was already turning, and the hundreds of people registered for emigration to Brazil quietly dropped the plan.

With the exception of one man of Danish origin who migrated to the Middle West in $1865,^{2}$ Icelanders showed no indication of joining the main stream of Scandinavian emigrants during the 1860 's. The Brazilian project may have arrested the initiative, and emigration with no hope of assisted passage was perhaps regarded as idle speculation for the poor Icelanders. Information was, no doubt, scarce and organized transport non-existent.

Not until 1870 did a trickle of emigration start $(4,12$, and 23 known emigrants in that and the two subsequent years, respectively), directed towards the Middle West. Well-off families and vigorous young persons travelled on their own to Britain or Denmark where they could get the services of emigration agents. Newspaper coverage of America increased suddenly and a collection of letters from America was translated and published.

The breakthrough occurred in 1873 with emigration in one jump up to $5 \%$, surpassed already in the following year, and (after a year's pause) reaching its first peak of at least $17 \%$ in 1876 .

What had happened? Simply that Iceland had got its first emigration agency, that of the Allan Line. The agent advertised that the line would send a ship for a sufficiently large party of emigrants. Interested people in one area took the initiative, formed an association (like the ill-fated Brazilian one and centered in the same region) 
and sent a messenger to collect subscriptions in large parts of the country. In the spring of 1873 more than $14 \%$ of the whole nation had subscribed for emigration to either Brazil or North America.

The Allan Line did not send the emigrant ship but the agent managed to arrange an inexpensive journey to Scotland for the largest single group (about 150 out of 350). Smaller groups travelled as ordinary passengers to Scotland or even to Denmark and Norway, in the latter cases obviously refusing the services of the Allan agency.

The next year the Allan Line sent an emigrant ship to two ports of call in Iceland; few people now travelled by other (more expensive) means. A similar round trip was made to four ports in 1876 , now prepared by the publication of pamphlets and the activities of Canadian government agents in Iceland.

I do not suggest that the transportation offer was by itself sufficient to plunge Iceland into a state of mass emigration. Other circumstances must also be considered.

From about 1870 the climate grew milder again and fish catches were relatively good; one has every reason to assume that the economy was expanding and that Iiving standards were rising. But so were expectations, and progressively larger cohorts reaching adult age kept up the population pressure. Nor were Nature's favours unfailing: a volcanic eruption in 1875 affected emigration regionally, and the same may be true of bad spring weather in 1872 . On balance it is possible that the economic "push" to emigrate increased during the early 1870 's, but not by leaps and bounds. Political discontent certainly peaked in 1871-73; political motives were mentioned in an apologetic context by emigrant leaders, ${ }^{3}$ and these may have made some difference, although politics can hardly be envisaged as the prime mover of the ordinary emigrant.

Bearing in mind the general course of European emigration one may assume that by 1870 the "push/pull" action was strongly felt in Iceland but counteracted by initial obstacles. Perhaps the most crucial turning point ought, indeed, to be placed here, when emigration became continuous and increasing, although on a miniature scale, and information began to flow in. Nevertheless it is clear that the organized transport system established in 1873 did lower the threshold of obstacles enormously and so initiated emigration on a mass scale.

Now let us temporarily turn to another peculiarity of Icelandic 
emigration: the fact that the emigrants overwhelmingly settled in Canada rather than the United States. ${ }^{4}$

The young Dominion of Canada made the promotion of immigration one of its first priorities, especially after the westwards expansion of 1870. It tried to outbid its southern neighbour by a more generous Homestead Act, free inland passage, and lowered ocean fare together with a propaganda campaign in collaboration with the Allan Line. ${ }^{5}$ The establishment of an agency in Iceland must be seen as a part of this drive; one can speculate how far it was a keen response to the signs of emigration beginning and how far it was an active step to create a new recruiting area; in any case it was hardly an accident that the Allan Line of all lines made the Icelandic venture.

Generally this Canadian effort was a failure. The volume of European emigration began to shrink at the most inopportune time, and the dwindling stream of immigrants proved particularly difficult to deflect from its traditional destinations in the United States, probably even more so because it was dwindling and so, one may assume, to an unusual degree derived from earlier immigration.

Not so in Iceland. Icelandic emigration had hardly any traditional direction (although Wisconsin was chosen by most of the pre-1873 emigrants). It may have been extraordinarily costsensitive since the domestic price level was relatively low and money scarce. And the Icelandic emigrants were looking for a special kind of place to go. They wanted to form a separate settlement, a New Iceland. A farming community, of course, and they wanted to go directly there without an intervening wagc-earning period. In assessing sites, arable land was not paramount as they were only used to livestock farming, and they were more repelled by outlandish inconveniences like locusts than familiar ones like cold.

In the spring and early summer of 1873 most Icelandic emigrants went to the United States. The largest group departed late, accompanied by the line's agent. He persuaded most of the passengers to change their destinations from the Middle West to Muskoka, Ontario. ${ }^{6}$ And why shouldn't they comply? Their homesteads in Wisconsin were not ready; instead they had, to their disappointment, been advised to take work as farm hands with Norwegian farmers. Money was short as their livestock had sold badly; free inland travel a Iong way in roughly the desired direction must have weighed a lot with them. 
In 1874 practically all Icelandic emigrants intended to join their countrymen in Ontario; contemporary sources give free travel and a generous homestead offer as reasons. " The Icelanders had, however, fared so badly in Nuskoka that the authorities directed the newcomers to Kinmount, but they fared no better. In 1875 there was little emigration. The New Iceland had evidently not been found but it was being actively sought, and prospective,emigrants were advised to wait back home because of the depressed American labour market.

Three projects for the establishment of a New Iceland were proposed, all dependent upon special privileges. The first was sponsored by the government of Nova Scotia, which offered land and assistance in addition to that provided by the Homestead Act. Settlement began already in 1875, and the experience soon persuaded the government not to sponsor further development of the colony. ${ }^{8}$ In the same year a settlement in Alaska was proposed but it depended upon assisted passage. President Grant (for whom the slow development of the newly bought Alaska was a political liability) was won over to the idea, but Congress was not and that toppled the project. ${ }^{9}$ The third proposal was for an Icelandic colony in the Canadian West, on the model of the Mennonite settlements of 1874. A site was found on Lake Winnipeg (then outside the boundaries of Manitoba) and Icelanders granted exclusive settlement rights and limited self-government. The settlement was sponsored and financially assisted by the Canadian government, partly for humanitarian reasons as the plight of that unfortunate people seemed equally cruel in Ontario, Nova Scotia, and back in Iceland. (Besides, special cases, like the Mennonites and the Icelanders, seemed to be the only possibility to populate the Canadian West.) ${ }^{10}$

This last New Iceland (as was its official name) provoked a true exodus of enthusiastic Icelanders, from Eastern Canada already in the autumn of 1875 and from Iceland in the following year. Then there was little emigration in 1877 as New Iceland was quarantined because of smallpox, but in 1878 and '79 it again attracted hundreds of immigrants.

In the early 1880's New Iceland suffered natural and social calamities and the idea of a unified and exclusive Icelandic settlement was, in practice, given up. But by then Winnipeg had become the urban center of the Icelandic ethnic community and the most natural stepping stone for new immigrants, gradually encircled by Icelandic settlements. The pattern of emigration to Canada, thus 
established and reinforced by government-sponsored propaganda and even (in 1893) loans to pay fares, was not seriously disrupted, even if the Canadian economy did not, until 1896, compare favourably with that of the United States.

This course of events suggests why the Icelandic pioneers were relatively unaffected by the American depression, so fateful to European emigration in general. Not only would Icelanders have rather imprecise information about developments across the Atlantic and no clear standards of normalcy by which to judge them (this would apply to any people in its earliest phase of emigration); they also intended to become immediately largely self-sufficient as farmers and thus able to disregard the American labour market. The Canadian offer of a separate settlement was also a special "pull" factor.

From a more general point of view the emigration history of any nation (or other appropriate unit of observation) may be seen as the interaction of two logically distinct chains of events. One is the much discussed progression through the peaks and troughs of the semigration cycle", economically determined and paraflel for all parts of Europe. The other is the once-and-for-all passage through the sequential phases of emigration, ${ }^{11}$ a social rather than a purely economic phenomenon, similar in outline in most countries but different in its timing. (As far as I know there is a regrettable lack of comparative studies throwing light upon the interaction between the two, without which any study of the former on the macro level must be rather risky.) In Iceland, emigration potential had built up during the protracted intoductory phase to be suddenly released when the transport revolution of 1873 marked the beginning of the growth phase. This development completely overruled the downturn of the general emigration cycle, for reasons partly explained above. That downturn may even have led the Allan Line and Canadian authorities to intensify their recruiting efforts which in turn demonstrably speeded up the Icelandic phase sequence.

\section{NOTES}

1 Of a population of 72000 ; of course small units tend to produce extreme rates.

2 Borsteinn B. Dorsteinsson, Saga Íslendinga í Vesturheimi, II, Winnipeg 1943, p. 111.

3 Op. cit., I, Reykjavik 1940, pp. $184 \mathrm{f}$. 
4 Available sources, which may, however, be somewhat biased, suggest the ratio $12: 1$ for 1873-93.

5 See Kristian Hvidt, Flugten til Amerika eller Drivkrefter i masseudvandringen fra Danmark 1868-1914, Aarhus 1971, pp. 366 f. 386 f, 461-467; Norman Macdonald, Canada: Immigration and Colonization 1841-1903, Aberdeen 1966, pp. $31 \mathrm{f}, 46 \mathrm{f}, 108,110 \mathrm{f}, 125$.

6 Dorsteinsson, op. cit., II, p. 185.

7 Op. cit., I, p. $94 \mathrm{f}$.

8 Op. cit., II, pp. $301 \mathrm{f}, 310$.

9 Hjörtur Pálsson, Alaskafor Jóns Olafssonar 1874, Reykjavik 1975 (English summary).

10 W. Kristjansson, The Icelandic People in Manitoba, Winnipeg 1965, pp. 144, 147; Macdonald, op. cit., pp. 197 ff, 209 f, 322 (n. 69).

11 Sune Akerman, "Theories and Methods of Migration Research." From Sweden to America: A History of the Migmtion. Eds. H. Runblom and H. Norman, Uppsala, 1976, pp. 25-32. 